\title{
Continuity and Decline. Temporal Expression of Denominational Cemeteries in Contemporary Times
}

\section{Introduction - Difficult Heritage of Denominational Cemeteries in Time and Space}

Burial places, which have been evolving over thousands of years, have become an important criterion for defining cultural, religious and national identity ${ }^{\mathrm{I}}$. Cemeteries have not only been places where the dead are buried but also elements of the landscape that is shaped and created by man, which are very special due to their unique place identity that is difficult to remove. Genius loci in many cases determined its continuum - sacralisation of the original burial places (also called accommodation by Jacek Kolbuszewski (1996) or, quite the opposite - led to the intentional phasing out of the purposes served by the area (Wrzesiński 20I4: I55-I57; cf. Sacrum pogańskie - sacrum chrześcijańskie... 2010).

Denominational cemeteries are places the temporal continuity of which is strongly correlated to socio-cultural changes. Thus, they can become nearly 'frozen' within the landscape for centuries as material echoes of past generations. Cemeteries are frequently subject to destructive processes which, due to their sudden nature, can change the character of burial areas completely within months, weeks, or even days, sometimes virtually erasing them from the physical landscape. This is why cemeteries form heritage that is complicated in many different terms. As they combine the world of the living with the world of the dead, they have many emotional and symbolic resonances. They are among the indicators of identity and history of the community, holding it together, but

I Some even refer to a phenomenon called necronationalism (Domańska 20I8: 75-76). 
in many cases they are also manifestations of divisions within the community (in cultural and religious terms). And finally, as surface objects full of religious symbols, they are significant elements within the cultural landscape, which in a way organise the space, particularly on account of their strong semiotic aspect. During wars, cemeteries, sacred to given religious and local communities, are among the first elements of the cultural heritage destroyed by armies seizing the land and new, different in cultural and/or ethnic (and frequently also religious) terms, communities - new settlers. Such phenomena are called by Andrzej Stachowiak (20I6: 9I) 'censorship of graves'. After all, according to the words attributed to Ferdinand Foch, "Motherland is the land and graves. Nations, losing memory, lose their lives" (Kolbuszewski 1996: 5; Stachowiak 2016: 90).

Denominational cemeteries often operate for decades or even centuries. In consequence, they become very complex, which is determined by both space and the passage of time. Thus, it can be said that as elements of the landscape's surface layer cemeteries have:

a. A specific scope - they are objects developed horizontally, occupying space that is usually separated from the surrounding landscape by physiographic or artificial boundaries;

b. Continuity in time (Kolbuszewski 1996: 37) - some indicate that they have characteristics of a permanent space, even if only in formal terms.

This can be confronted with the words of Barbara Szacka:

[...] in the image of each country, two dimensions - spatial and temporal - seem to occupy a special position. One cannot help but notice that a shared territory and a shared past are the two most important identification elements of human groups (Szacka 2006: III).

As Barbara Lewicka points out (2012: 93), cemeteries combine the two categories cited (and listed above). However, this is only one of the reasons why they are such significant elements of the cultural landscape.

Even within a relatively short period from the middle of the $20^{\text {th }}$ century to the contemporary times, the denominational cemeteries located in the territory of Poland have indeed become cultural texts, as indicated by Jacek Kolbuszewski (1996; cf. Długozima 2016: 16). Texts that collect the stories of people and religious, ethnic and national groups they form, but mostly of communities connected with a given land, which have forged the identity of not only states but also their personal micro-homelands (cf. Jaszczak, Dreksler 2013). Over more than seventy years that have passed since the end of the Second World War, denominational cemeteries have undergone transformations worth presenting and systematising. Starting with a more general analysis and gradually moving towards the stories of individual places 
presented here, I will indicate a certain spectrum of spatial and temporal changes of cemeteries, which will explain why cemeteries can be referred to as examples of difficult heritage, mostly with regard to aspects connected with the (im)permanence of their material substance.

\section{The Research Aim and Hypothesis}

The main aim of this paper is to indicate and attempt to systematise, based on the criterion of the anthropogenic effect, the main directions of transformations taking place in the contemporary times in denominational cemeteries located in the territory of Poland. The analyses were limited to the period from the end of the Second World War to the present.

The research hypothesis formulated predicted that contemporary material structures and spatial arrangements of cemeteries result from the process of diversification of burial areas taking place over time due to natural and cultural conditions.

It was extended by an assumption indicating the dominant types of transformations of cemeteries in the temporal extension of the present time, identified based on the directions of the anthropogenic activity. Theoretical model paths of the temporal expression of cemeteries are presented on the graph below.

The notion of the cemetery's temporal expression was presented by Jacek Kolbuszewski in one of his works:

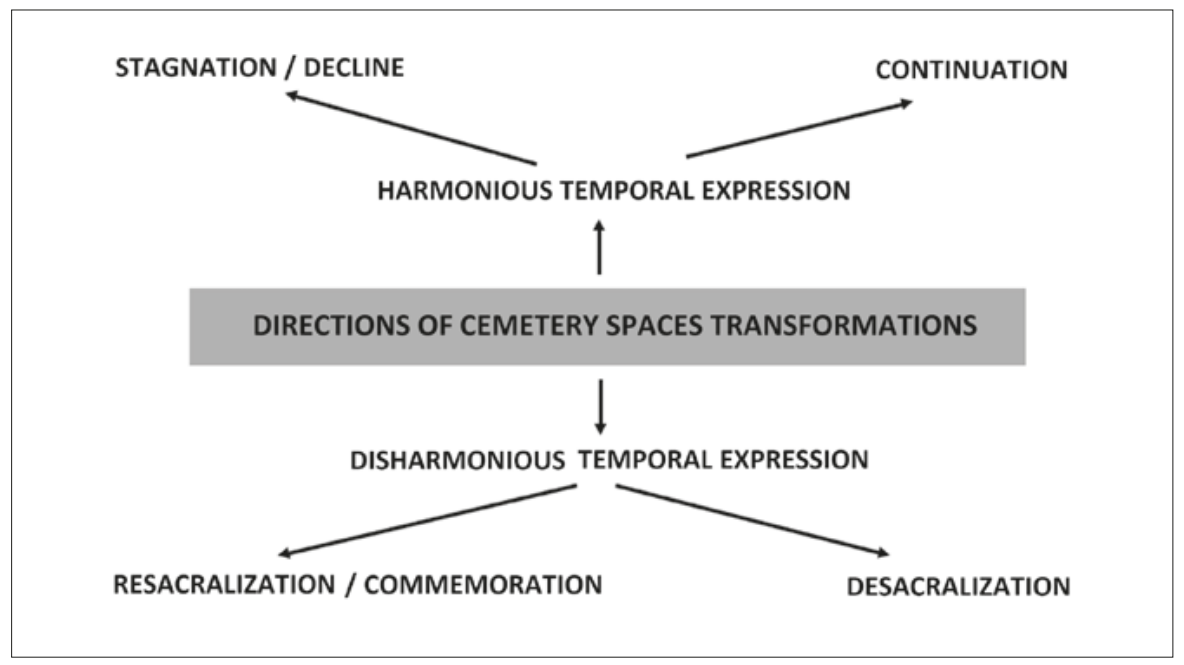

Fig. 1. Directions of the leading transformations of cemeteries based on the criterion of the anthropogenic effect (prepared by A. Majewska). 
Thus, there is something paradoxical about the fact that even though the actual essence of a cemetery is constituted by the bodies buried in the ground, the carriers of all meanings expressed by it are, in fact, elements forming its above ground infrastructure. And they are mostly the reasons why cemeteries become important cultural phenomena or, in other words, the already mentioned cultural texts. This is where our present meets the past in a tangible way. A cemetery, so to speak, does not only develop in space but also in time, gaining a certain temporal expression (Kolbuszewski 1996: 37; boldfaced by the Author).

The idea of the cemetery's temporal expression refers to the concept of time from the relational perspective, which is described by Zbyszko Chojnicki as follows: "just like the spatial distance is a separation between things, the temporal interval is a separation between different states", so it concerns continuity as a distance "between states of changing things, i.e. events or processes" (Chojnicki I999: 254). Thus, the past, the present and the future of a cemetery are organised by different 'states of things', separated by a temporal interval.

Harmonious temporal expression involves transformations of a relatively uniform character, which are not invasive activities aimed at, for example, changing the purpose of the cemetery. Harmonious temporal expression takes place through continuation of the activity connected with the original use and the denominational status of the cemetery. It can also include periods of stagnation in the anthropogenic activity or its gradual disappearance in the area.

Disharmonious temporal expression appears as a result of a conflict between the original and the contemporary uses of the cemetery, for example, in consequence of its resacralisation - transformation and the granting of meaning by representatives of a different religious/denominational group, and possibly commemoration, or due to complex desacralisation processes: transformation of the cemetery for the purposes of the economic activity.

It has to be emphasised that the directions of the leading transformations of cemeteries ${ }^{2}$ described further in this paper are not disjunctive. Individual categories of transformation can concern the same object at different stages of its operation and presence in the cultural landscape, undergoing various processes and co-determining the changeability of the temporal expression. These

2 Issues concerning factors that determine the transformation of cemeteries and stages of changes taking place within them have already been raised by some studies into burial places in the territory of Poland. Proposals of more or less complex systematisation of these conditions have been put forward. For example, factors determining the fate of cemeteries are cited from A. Brencz (2000) by A. Stachowiak (2016: 92), and divided into two main types of factors: objective (administrative and economic regulations, natural conditions) and subjective (cultural conditions, e.g. "the effect of traditional cultural models or introduction of new solutions that imitate foreign models"). 
processes, even though described separately, can occur in a given place simultaneously, e.g. a continued use of a cemetery and its desacralisation in the form of secularisation (e.g. parts of Jewish and Christian cemeteries in large cities).

\section{The Study Scope and Methods}

The research proceedings assumed a qualitative paradigm, as part of which an analysis path was determined based on a study of the historical and factual literature raising the issue of socio-political transformations and the situation of denominational groups after the Second World War, and particularly factors determining the way burial places such as cemeteries function. The research subject only covers places with a surface layer - historical cemeteries, however, on account of the complexity of the issue, only those that originated in the modern age. Only cemeteries with skeletal burial grounds were considered, or those with columbaria or separate quarters for urn burials.

Each of the directions of transformations distinguished was illustrated with a brief description of the processes that have taken place in the selected cemeteries. The processes discussed were selected based on the identified stratigraphy of contemporary cultural accumulations in the cemeteries ${ }^{3}$. The cemeteries were selected from among the places the Author had analysed in her previous research as the ones that best exemplify a given model of the temporal expression of cemeteries. Detailed analyses of burial grounds were based on the study of the literature, archival materials, and field documentation of the material structures of cemeteries, and on the observations made, which allowed to draw conclusions with regard to the changes taking place in time and space.

The paper does not contain any exhaustive discussion on the leading categories of the changes indicated, which was substituted with the explanation of terms only to the extent they are applied in connection with the material characteristics of the cultural landscape (material culture) of, in this particular case, cemeteries.

\section{Harmonious Temporal Expression}

A stage in the functioning a given cemetery in the landscape that can be called harmonious temporal expression involves uniform processes leading to gradual changes in the structure of the cemetery (without contradicting its unique character). This type of changes over time can be divided into two main directions of transformations:

3 More about the substantive basis: Myga-Piątek (2005: 73-74). 
a. Those taking place with the involvement of the community that established the cemetery and continuous to use it (which means burying the dead in the cemetery and/or interfering in the physiognomy of the cemetery in order to preserve its original character and/or following regular religious practices in it);

b. Those connected with the gradual cessation of the use of the burial ground, where after the burials stop (regardless of the reason for this), the dominant role in the transformations taking place in the cemetery is played by natural processes connected with the way the natural environment functions.

\section{Continuation}

Continuation of the use of a cemetery in the present means the use of the burial ground in accordance with its purpose by the denominational group that established the cemetery. Such processes are most common in Poland in Roman Catholic cemeteries, which reflects the contemporary denominational struc-

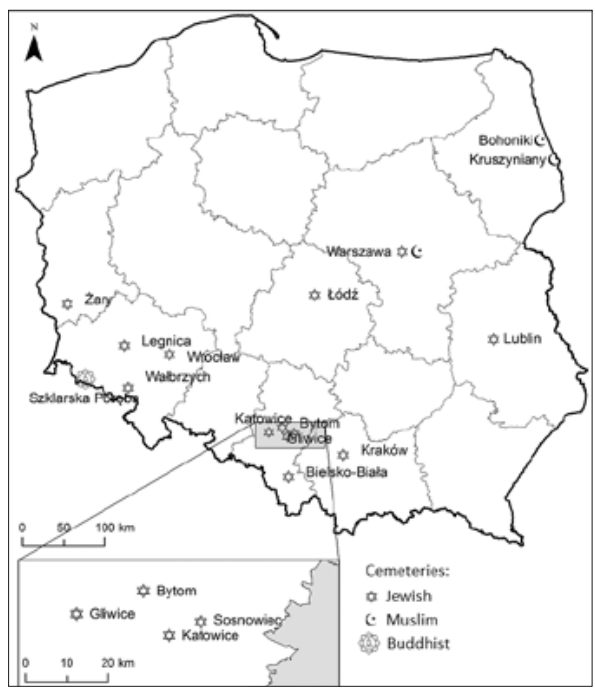

Fig. 2. Operating non-Christian cemeteries in the territory of Poland, as of 2017 (prepared by A. Majewsk based on: Muslim Religious Community in the Republic of Poland - www.mzr.pl, access 2 XII 2017; Rykała (2007); Majewska (2016b); Wspólnota bez Bram Mumon-Kai - http://www.mumon-kai. com/polen.html, access 2 XII 2017). ture. However, burials also take place in a number of cemeteries belonging to denominational and religious minorities, including Christian cemeteries: Orthodox and Protestant, and non-Christian cemeteries: Jewish, Muslim etc.

Particularly in the case of cemeteries in which religious principles forbid to disturb the graves (rendering their reuse impossible), internal landscapes reveal temporal and visual changes taking place in the material, above ground tissue of necropolises. These can be seen, for example, in the Tatar cemetery (mizar) in Kruszyniany. Visitors go around this Muslim (Tatar) cemetery as if following a timeline, passing simple headstones with weathered inscriptions from the $17^{\text {th }}$ century, and gradually reaching modern, unified gravestones. 
Apart from that fact that, as churchyards, they are denominational objects, cemeteries in small towns and villages are frequently treated by experts in the area mostly as mirror images of the communities that use them. This is confirmed by, for example, the anthropological reading of the area of a rural cemetery located in Złoty Potok in the Kraków-Częstochowa Upland made by Grażyna Ewa Karpińska (2017).

The cemetery that was analysed by the Author as a case study concerning the transformation of a burial area in the context of the continuation process is the old parish cemetery in Lelów. It was established on a castle hill probably in the I830s, on the remains of a defensive building (a wooden structure) erected there probably as early

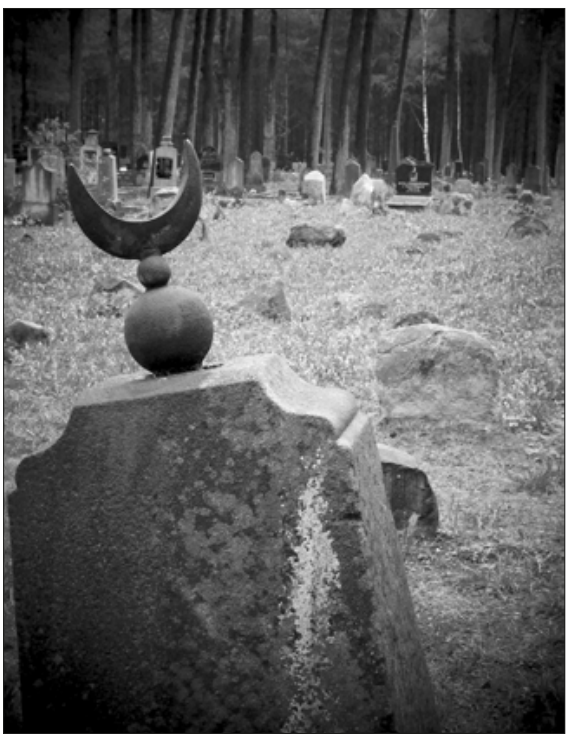

Fig. 3. The area of the mizar in Kruszyniany; a traditional headstone in the foreground, and a unified, contemporary gravestone in the background (photographed by A. Majewska). as at the end of the $13^{\text {th }}$ century. The brick building erected in the $14^{\text {th }}$ century during the reign of Casimir III the Great was altered a number of times over the following centuries, and ultimately pulled down at the beginning of the I $^{\text {th }}$ century (Laberschek I99I: 530; Widawski 1973: 238). This is also indicated by the oldest graves identified in the cemetery with non-invasive methods. They come from the years: 184I (Fig. 4), I849, I850, so from a period when Lelów still had town privileges (which it lost in 1869). Based on the inventory data (a total of 490 separate burial plots were documented), it was possible to determine a hypothetical direction of covering the area of the castle hill with graves (cf. Majewska 2017: 64-65) (Fig. 5). Graves were reused in the cemetery even in 2015 and 2016, which means it has operated continuously for nearly 150 years. Interesting aspects of the functioning of the place are small changes taking place on the level of its material structure, which also prove that the community cares about the local history, its continuity in time, and its material evidence in the cemetery. An example of this is the grave of Paweł Michalak, who was born in Mełchów on June I3, I924, and, according to the inscription: "DIED FOR HIS COUNTRY / ON AUGUST I, I946 / KILLED BY UKRAINIAN BANDS / IN THE TOMASZÓW LUBELSKI / DISTRICT / FOUNDED By / INHABiTANTS OF THE LELÓw COMMUNE". A simple gravestone 
from the middle of the $2 \mathrm{O}^{\text {th }}$ century in the form of a plinth with a cross was later replaced with a larger, granite gravestone with an upright slab, following new aesthetic standards (Fig. 6) ${ }^{4}$.

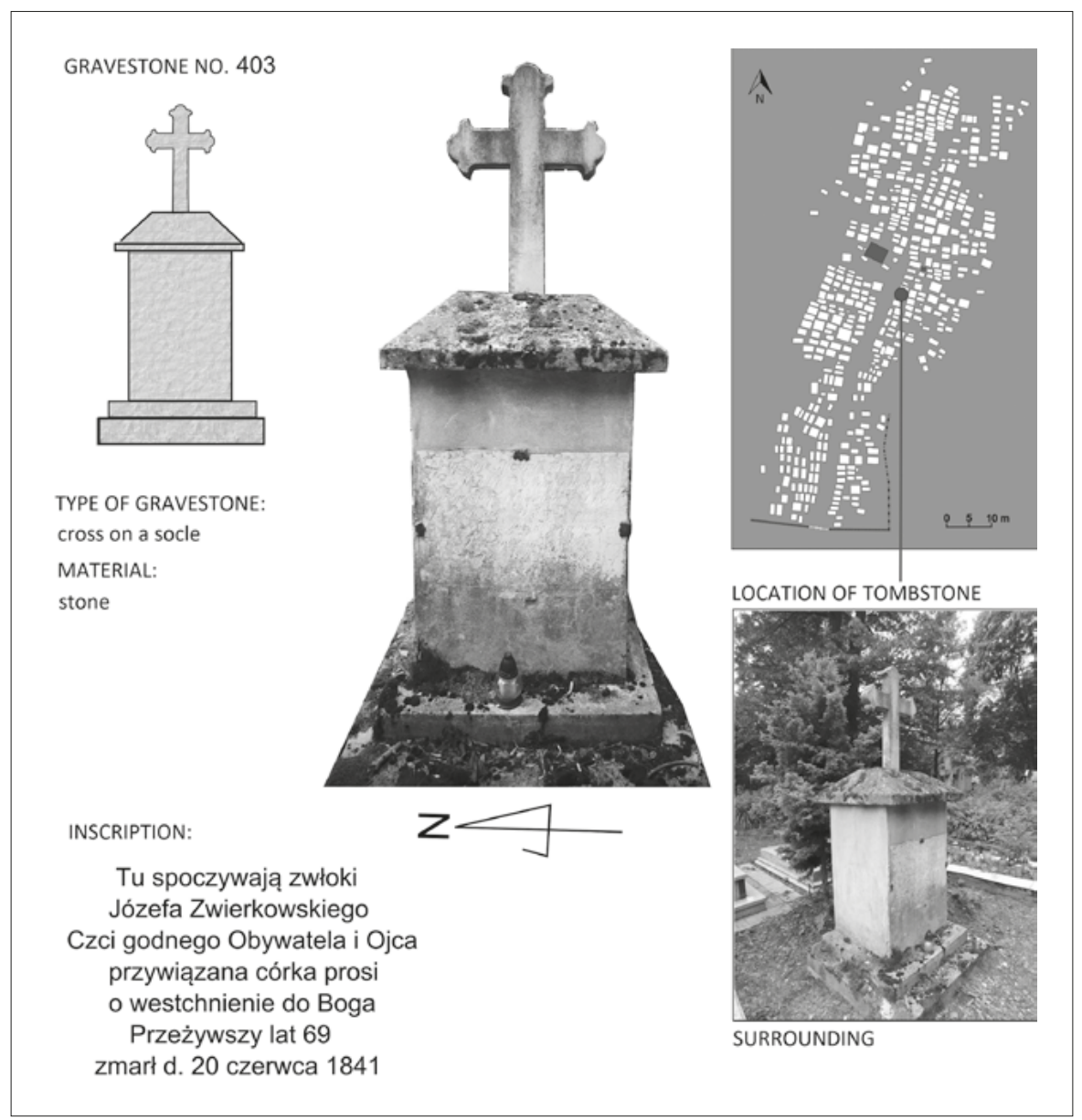

Fig. 4. The oldest (according to the date provided by the epitaph) gravestone in the parish cemetery in Lelów. Locations of gravestones with dates of death up to 1850 (photographed and prepared by A. Majewska).

4 The Author conducted research in the cemetery in Lelów in 2016 together with students from the Institute of Archaeology of the University of Łódź. It was conducted under the project funded by the National Programme for the Development of Humanities "Places of Remembrance and Oblivion. Interdisciplinary Research of the Northern Part of the Polish Jurassic Highland" (manager: O. Ławrynowicz). 


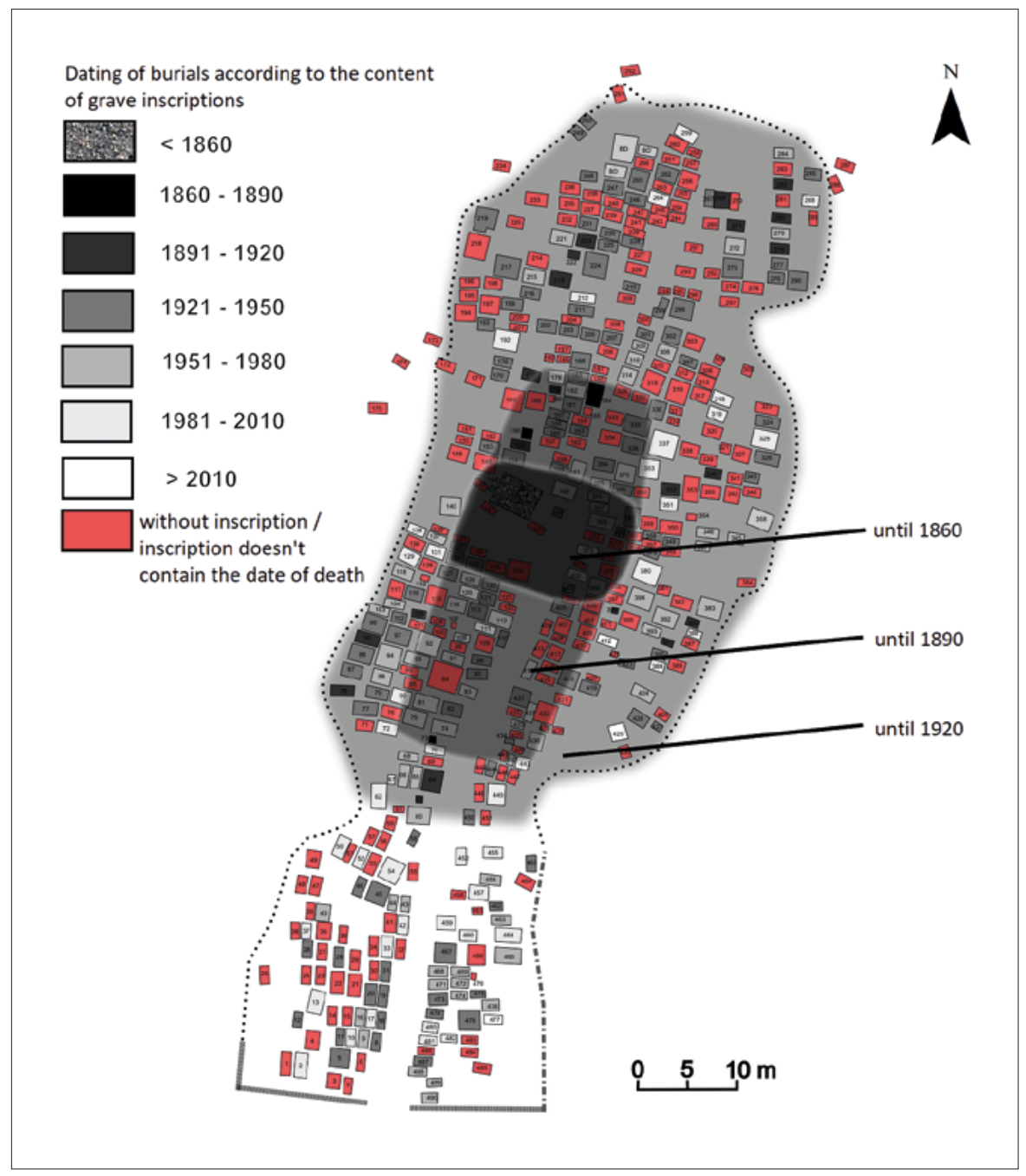

Fig. 5. The cemetery's spatial development: changes in the reach of the graves in the Roman Catholic cemetery in Lelów (prepared by A. Majewska).

A continued use of a cemetery by the denominational group that established is possible only if the burial function is upheld. This can be connected with conducting religious ceremonies in the cemetery and/or following traditions that are not related to any burial rites but are reflected by changes in the material structure of a given cemetery. Such phenomena concern, for example, Jewish necropolises that are used for religious purposes even though they 


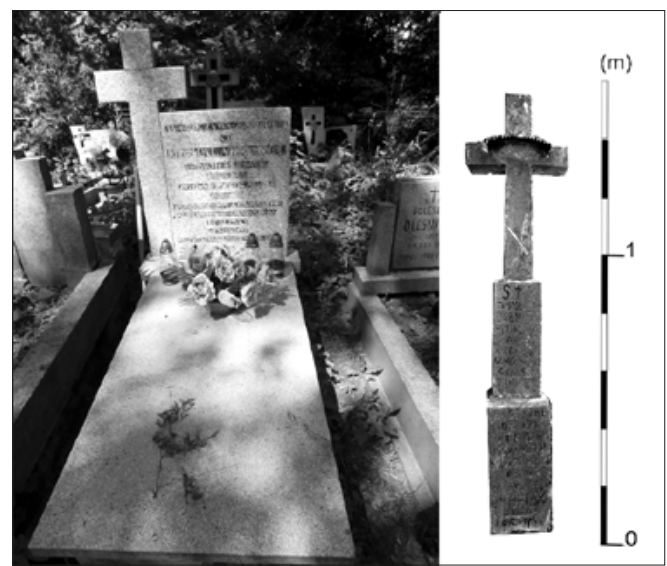

Fig. 6. Gravestones in the Roman Catholic cemetery in Lelów - an example of a replaced gravestone (photographed and prepared by A. Majewska). no longer serve burial purposes and, in many cases, despite considerable damage suffered during the Second World War. This can be exemplified by the cemetery in Leżajsk. A famous tzaddik Elimelech Weissblum was buried there, and his remains rest today in a place over which a grand ohel was built ${ }^{5}$. Every year, on the twenty-first day of Adar, which in the Gregorian calendar is in early spring, groups of pilgrim Hasids come to the town and pray over the tzaddik's grave (Gładyś, Górecki

2005: 246) (Fig. 7). The grave is also frequently visited by Jews from many different countries all over the year. Hundreds of notes left at Elimelech's grave (kvitelach) with petitionary prayers for intercession with God and candles that are often lit inside constitute a certain continuation of the function of this unique place. They are superimposed on its material cultural heritage even though it remains extremely ephemeral as the notes are burnt as soon as the pilgrims leave the town (Malchrowicz-Mośko, Grzesiak 20I3: 37). The cemetery
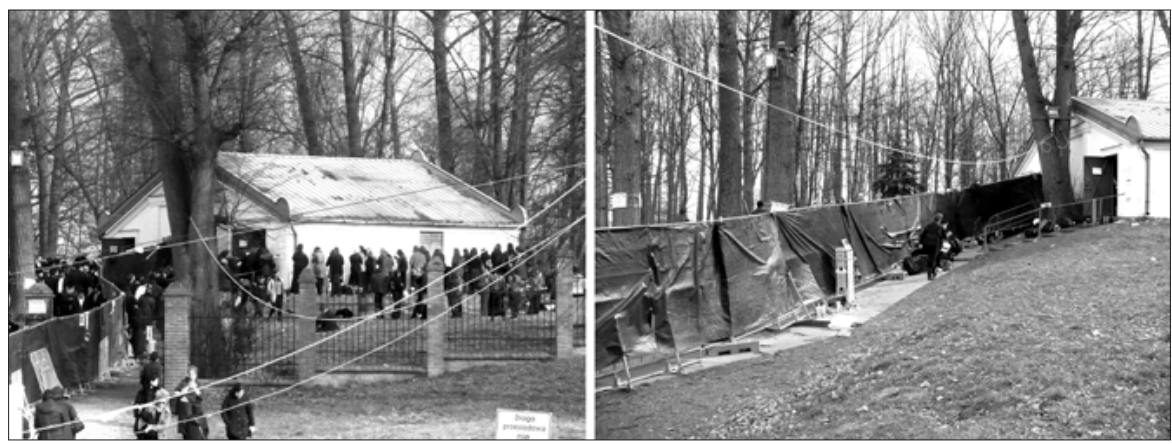

Fig. 7. The Jewish cemetery in Leżajsk on an anniversary of tzaddik Elimelech's death. Temporary changes in the cemetery's landscape and structure: division of the space into areas for men and women (photographed by A. Majewska).

5 In Leżajsk, it is an architectural tomb in the form of a small building with a separate room in which women can pray, and the main room with the tzaddik's grave. 
in Leżajsk, apart from the area referred to by Jews as the 'house of graves', has also become a destination of temporary religious migrations of members of Hasidic religious communities.

A continuation of use is similar, even if less frequent, in other Jewish cemeteries with graves of wise men and leaders of Hasidic communities. It is worth mentioning Lelów (Częstochowa District), where an old Jewish cemetery, thanks to the Nissenbaum Foundation and Fundacja Chasydów Leżajsk Polska, was also transformed on the surface. The area of the cemetery was tidied up (after the Second World War it was partially developed), and an ohel of tzaddik Dawid Biderman was erected in its southern end (Majewska 2016b: 96; cf. Żydzi lelowscy: obecność i ślady... 2006). Cemeteries owned by denominational minorities are also places that help maintain community relationships, which sometimes results from the fact that burial places remain the only elements of cultural heritage one can tangibly identify with as they are the only elements to be still visible in the physical landscape (which is mentioned by Andrzej Rykała with regard to the Karaite minority, whose material cultural heritage in Poland includes only one cemetery located in Warsaw (Rykała 20II: 23-24).

\section{Stagnation/Disappearance}

One of the causative elements that determine other changes occurring in cemeteries is the official cessation of burial, which is connected with a legal change of the status of the place regulated in Poland by the Act on Cemeteries and Burials. This also co-defines the processes taking place in cemeteries the Author refers to as 'stagnation/disappearance.' The main indicator of this direction of transformations is the disappearance or complete cessation of any anthropogenic activity in a given place. Then, the decisive factors with respect to the changes occurring in the material structure are natural processes that are mostly destructive, such as weathering (chemical, biological etc.) and mass wasting ${ }^{6}$. Joanna Wałkowska, following the concept of H.J. Eggers, compares the domination of the cemetery tissue by (post)deposition processes aimed at the transformation of a necropolis into an archaeological site to the transition from 'living culture' to 'dead culture' and an oscillation between these two stages (Wałkowska 2017: 95).

The direction of anthropogenic transformations referred to as stagnation (temporally unspecified cessation of transformations resulting from the human activity) or disappearance (complete or nearly complete cessation of the human activity within a cemetery that is difficult to clearly define) frequently disrupts the cultural continuity in a given area. This may be connected with armed

6 More about the relationships between the anthropogenic activity and natural processes can be found in: A. Majewska (2016a: 259-266). 
conflicts (e.g. extermination of the population), political transformations or natural disasters, as a result of which the heritage of a given community or religious group is left heirless. Apart from the processes related to disharmonious temporal expression, places that are foreign in cultural and/or religious terms frequently enter a stage of functioning within the cultural landscape during which the dominant role in their transformation is played by natural factors. Out of the contemporary denominational cemeteries in Poland, the group in which processes connected with changes in the material structure in the $20^{\text {th }}$ and $2 \mathrm{I}^{\text {st }}$ centuries were to a large extent affected by natural processes includes cemeteries that used to belong to many local denominational communities. These were mostly minority communities, however, a lot of them dominated in the population structure of their settlement units. Most of them were Jewish and Protestant and communities destroyed during and as a result of the Second World War. The latter ceased to exist predominantly because of the Holocaust, and the former due to repercussions of the national affiliation and the destructive policy towards the previous cultural continuity (cf. Długozima 2016: 2I; Sakson 20I7: II7-I23; Stachowiak 20I5). Evidence of their former existence includes, among other things, material heritage that still co-creates the cultural landscape but outside its original social context. This is what happened to, for example, Masurian Evangelical cemeteries (cf. Żurkowska 2008). Many of those located in forests or thinly populated areas suffered from rapid degradation of their material structure. Graves overgrew and inscriptions on raw headstones weathered. In many cases, after devastation during or right after the war, it was the forest and not people that re-annexed the cemetery area (Fig. 8). Stagnation in the anthropogenic effect on the cemetery tissue followed

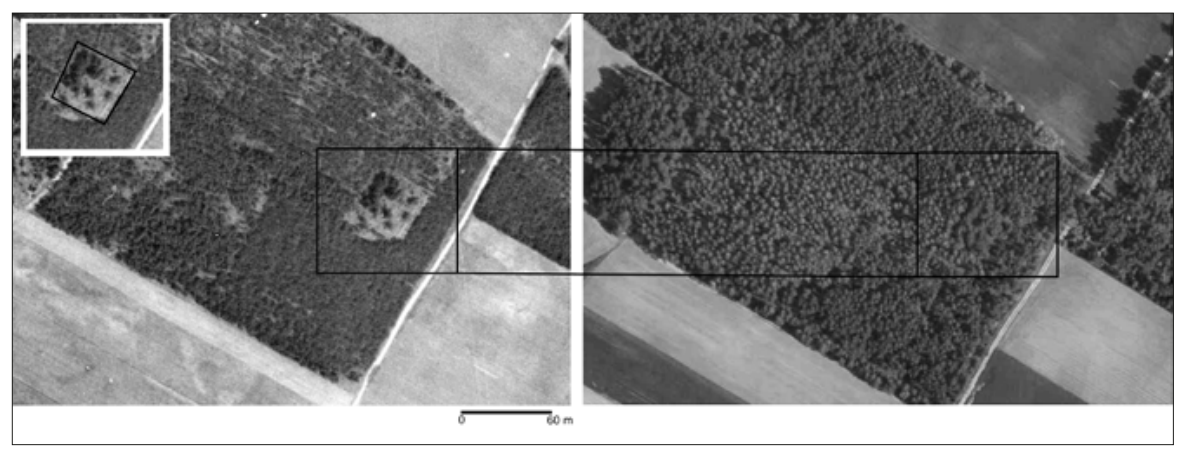

Fig. 8. The area of a mid-forest Evangelical cemetery in a former village of Kosaki (Pisz District) in aerial photographs from: a) 1979; b) 2015 (prepared by A. Majewska based on the materials from: www.geoportal.gov.pl; a photogrammetric photograph, file no. 8_6773, from the collection of the Main Centre of Geodetic and Cartographic Documentation). 
by its cessation, ending in complete natural destruction, and in some cases also planned liquidation of its surface (and/or underground) part, sooner or later concerns virtually all denominational cemeteries.

\section{Disharmonious Temporal Expression}

A stage in the functioning of a given cemetery in the landscape that can be called disharmonious temporal expression usually means dynamic processes leading to changes in the structure of the cemetery (frequently in contradiction to its original denominational and/or physiognomic and/or functional character). This type of changes over time can be divided into a few general directions of transformations, which usually take place without any involvement of the community that established, used or continues to use the cemetery.

\section{Desacralisation}

According to the Author, it consists of two main processes: secularisation and profanation of the cemetery area. Unfortunately, there are few studies concerning this issue. Some of them, even though their titles refer to the direction of changes, e.g. Niegdy's sacrum, dziś profanum - dawne cmentarze ewangelickie Poznania i okolic (The Sacred in the Past, the Profane Today - Former Evangelical Cemeteries in Poznań and Nearby Towns) (Rydzewska, Krzyżaniak, Urbański 20II), do not offer any elaborate theoretical deliberations. Transition into the profane seems to be mostly understood by authors as interference in the material structure: destructive activities with the aim to remove the cemetery visually from the landscape, and this is the most common approach. Desacralisation processes taking place in denominational cemeteries in Poland after the Second World War have been frequently connected with a period of deculturation of the landscape indicated by Wiktor Knercer, which means removal of any visible traces of the presence of heritage that is 'foreign' to new settlers (Knercer 20I6: II; cf. Kopczyńska 20IO). When discussing the transition of cemeteries from the sacred to the profane, it is also worth emphasising the dichotomous character of the processes we deal with. According to the Author, desacralisation as a direction of transformations concerning cemeteries consists of two main processes:

a. Secularisation - a desacralisation process mostly taking place through interference in the material structure of a cemetery, which leads to changes in its symbolic dimension; it particularly concerns the removal of the 
characteristics determining the cemetery's religious/denominational character/specificity through different activities, such as adaptation of the cemetery's concept - a park/garden, unification of graves etc., at the same time preserving differentia specifica of the cemetery - also known as secularisation of the burial space; it is often an expression of secularisation, acculturation or assimilation (desacralisation understood in this way is presented by, for example, Irmina Gadowska (Gadowska 20I7; cf. Kacprzak 2017: 9). Secularisation does not have such a negative overtone as profanation, which takes place within religious heritage of a given religious community against the will of its members and/or heirs to the cultural heritage, while secularisation can take place with consent of the members of a religious community the heritage is connected with;

b. Profanation - according to Arkadiusz Fordoński, it means physical violation of sanctity and "granting the act a character of an act of violence" (Fordoński 20I5: 38); desecration of a place/places of burial refers particularly to devastation aimed at the elimination of the material surface and/ or underground structure of the cemetery, which determines its character and purpose. Profanation processes, particularly brutal in their material dimension, took place during the Second World War in Jewish cemeteries. In many cases, they also continued after the war. A disgraceful example of such practices is the transformation of the material structure of the Jewish cemetery in Lubliniec (Silesia Province), where the pre-funeral house located in the cemetery was taken over by the State after the war, and in the ragos it was handed over to a driver training centre of the State Defence League (Białas no date). A part of the Lubliniec Jewish cemetery, which had already been considerably devastated before 1945, was used for business purposes, with a part of it being converted into a manoeuvre practice area (Wirtualny Sztetl). The remains of gravestones were collected from the cemetery area, and a disposal site was created for them in its periphery (Fig. 9). Relics of the profanation are still quite clearly visible in space (e.g. black slag, concrete kerbs, and even car tires found between the gravestones) even though the Jewish cemetery was tidied up in the last few years and marked with an information board. However, it has to be emphasised that while Jewish cemeteries are more and more frequently subject to restoration and become significant elements in the process of reinstating and creating memory of prewar Jewish communities, profanation of rural and family Protestant cemeteries, located far from human settlements, remains a serious problem. In these cemeteries, 


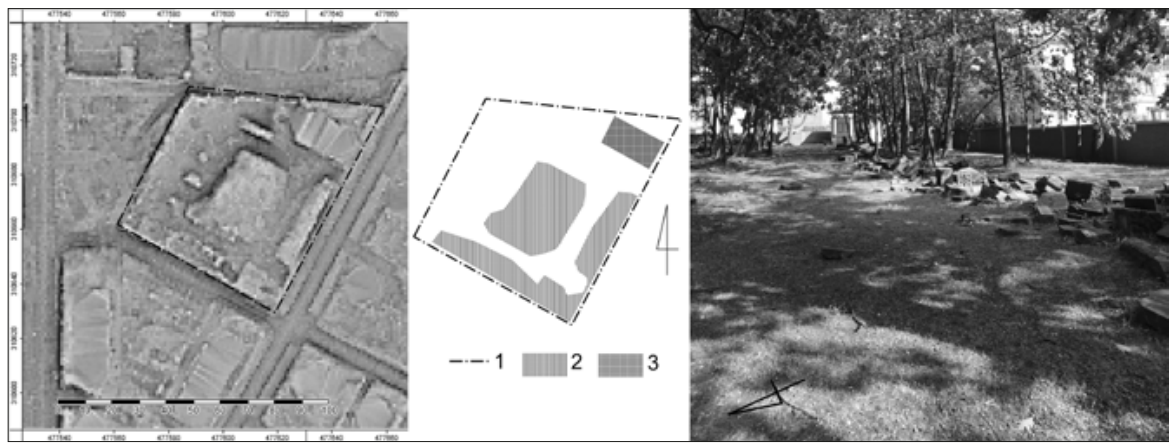

Fig. 9. Desacralisation of the Jewish cemetery in Lubliniec; the numbered elements: 1. cemetery boundaries; 2 . matzevah disposal site; 3 . location of the preserved part of the architectural tomb of the Koenigsbergers (photographed and prepared by A. Majewska).

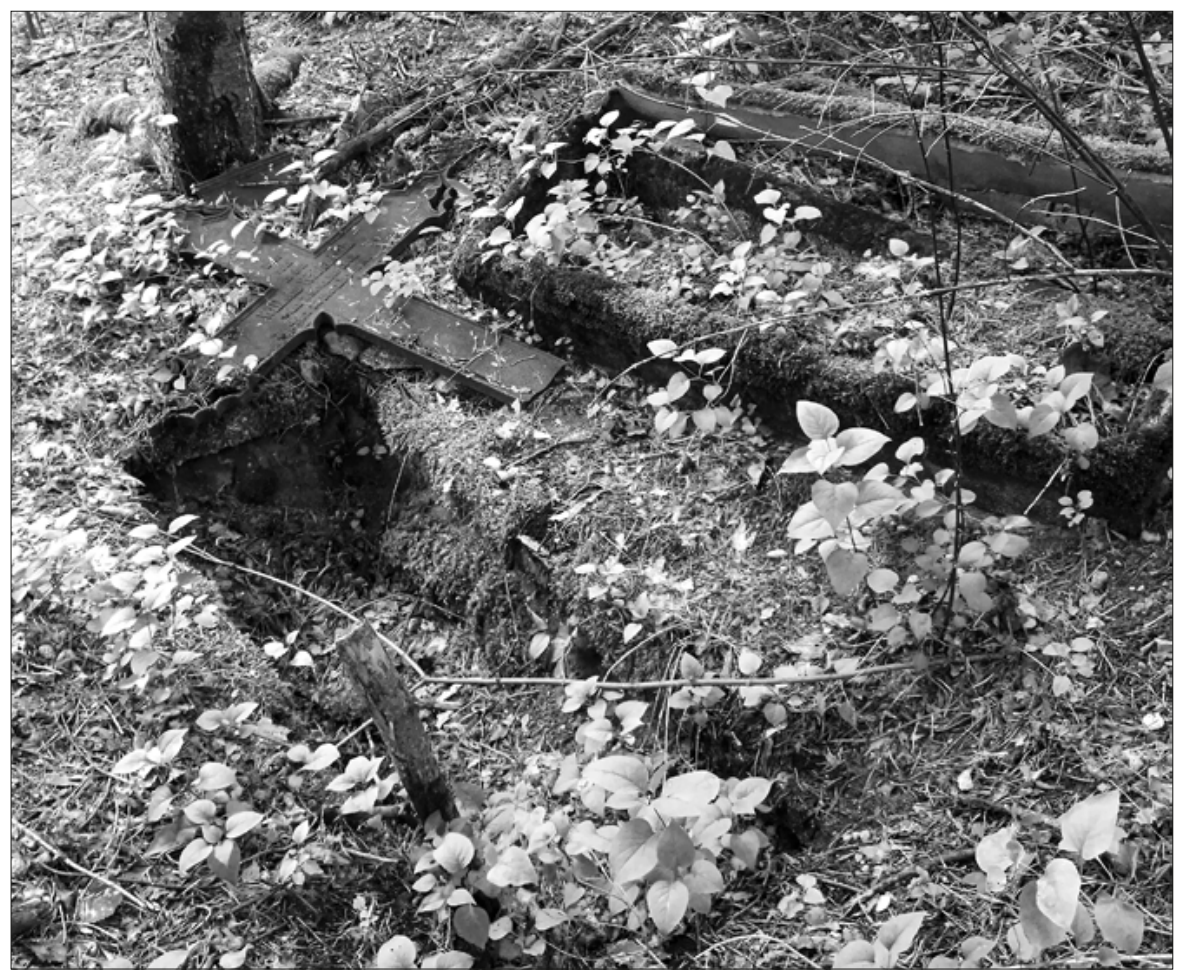

Fig. 10. A cemetery located deep in the forest, near the village of Pogorzel Wielka (Pisz District). A devastated and probably robbed grave. At the end of the 1980s, one could still see a coffin with scattered remains in the desecrated, open grave (photographed by A. Majewska; archival photographs for comparison from the documentation of the Ełk branch of the Provincial Office of Monument Preservation, Cemetery Card no. 1909, filled in by D. Gospodarek, 1989). 
much more frequently than in the Jewish ones, one can see evidence of profanation going beyond the devastation of the surface structure and concerning the desecration of what is, in fact, most important, i.e. human remains (Fig. IO).

\section{Resacralisation and Commemoration}

Resacralisation and commemoration are mostly connected with adaptation processes: assimilation and adaptation of heritage. Explaining the term 'resacralisation' as a modification of the term 'sacralisation', it can be said that it is (on the material level) restoration of the religious character of spatial elements (Stownik wyrazów obcych 2000: 988). On the other hand commemoration, despite being synonymous, has no direct relationship with the sacred within the extraliturgical sense. It also covers secular commemoration.

In this paper, the Author would like to present a unique case of processes taking place today in a cemetery, which can be described as resacralisation and commemoration (the material expression of which is even considered to be barbaric $\left.{ }^{7}\right)$. Transformations of this kind take place in the cemetery in Justynów (East Łódź District), which was established probably in the first half of the $2 \mathrm{O}^{\text {th }}$ century when a colony for German settlers was created ${ }^{8}$. At the time, it was located on the periphery of the village, approximately $70 \mathrm{~m}$ from today's Łódzka Street, south-east of the homesteads. After the land had been parcelled out for residential purposes in the $20^{\text {th }}$ century, the cemetery was surrounded by buildings (Fig. II). After the Second World War, it was taken care of by St. Matthew's Church of the Augsburg Confession from Łódź. People were buried in the cemetery until about 1960, and then it was closed for burial purposes (and the parish put it up for sale). The area was purchased by private persons, who still take care of this burial place today ${ }^{9}$. About IO-I2 years ago, some of the remains in the southern part of the cemetery were exhumed, and now there is a group of cenotaphs there (Fig. I2). Many of them may cause controversy due to a compilation of forms of remembrance of publicly known people (e.g. those holding public offices and artists, such as Cyprian Norwid, and images of Saint John Paul II, Maria

7 Such an opinion about the transformations taking place in the cemetery in Justynów was expressed by the Author of a website devoted to Evangelical cemeteries in the Łódź Province - cf. http://www.cmentarzeewangelickie-lodzkie.pl/justynow.htm, access 4 XII 2017.

8 In Studium uwarunkowań i kierunków zagospodarowania przestrzennego gminy Andrespol it is dated to 1890 (Studium uwarunkowañ... 2015: 78).

9 According to the information obtained from the people taking care of the cemetery. 
and Lech Kaczyński) made on a small area as well as references to the history of the $20^{\text {th }}$ century (e.g. the Holocaust, the Katyn massacre, with such inscriptions as: "KATYN / SMOLENSK / THE COST OF THE TRUTH IS SO HIGH", and a cenotaph devoted to Russian and Polish soldiers who fell in the territory of Poland) (Fig. I3). Furthermore, the material historical substance of the cemetery was reused to build a new, contemporary context as the cenotaphs were made of fragments of Evangelical gravestones. At the back of the gravestone of Auguste Schmidt, who died at the beginning of the $20^{\text {th }}$ century, an epitaph in memory of Juliusz Słowacki and Adam Mickiewicz was carved (Fig. I4). On the cemetery gate, there are boards with the following information: "CEMETERY / OF THE POLISH COMMUNITY / ALL OVER THE WORLD / AND OF THE WORLD IN POLAND", and boards referring to the Evangelical content: “THE VALLEY / OF DRIED / BONES / SO IN EVERYTHING, DO TO OTHERS WHAT YOU / WOULD HAVE THEM DO TO YOU / FOR THIS SUMS UP THE LAW OF THE PROPHETS".

Today, one can clearly distinguish two stages of the cemetery's operation in time:

The $\mathrm{I}^{\text {st }}$ stage - the cemetery's operation as an Evangelical burial place;

The $2^{\text {nd }}$ stage - the cemetery's operation as a 'garden of remembrance'.

The cemetery in Justynów is a case study that clearly shows transformations of the material structure of cemeteries taking place in the present as they have a very distinct form of a palimpsest (cf. Kijowska, Kijowski, Rączkowski 20II: I05-IO7). While a part of the former surface structure of the cemetery was erased from the physical landscape (approx. 30 legible graves remained), some new elements appeared that are commemorative and not genetically connected with the way the cemetery was originally used. It is worth emphasising that the only cenotaph referring to the historical

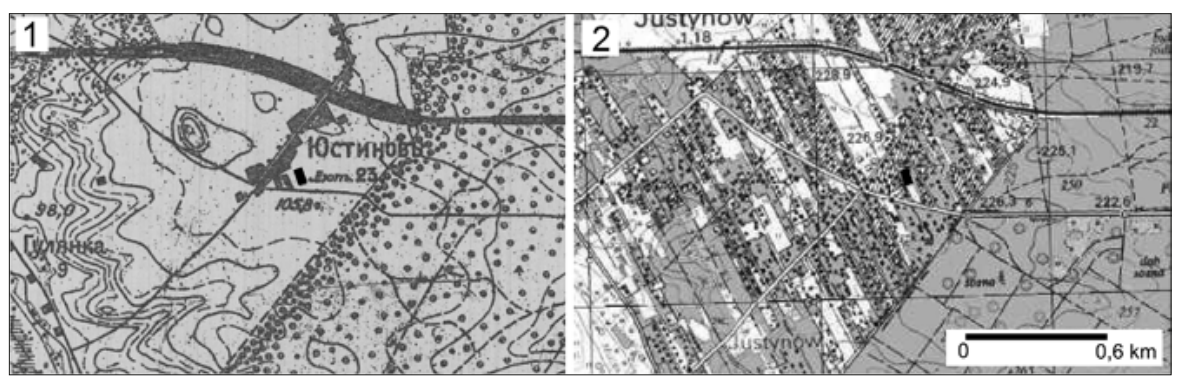

Fig. 11. Justynów on a topographic map from the second half of the $20^{\text {th }}$ century and on the map from 1931. Location of the cemetery is marked in black (prepared by A. Majewska based on the following sources: www.geoportal.gov.pl; a topographic map 1: 25 000, sheet: 42-29-C, WIG, 1931). 


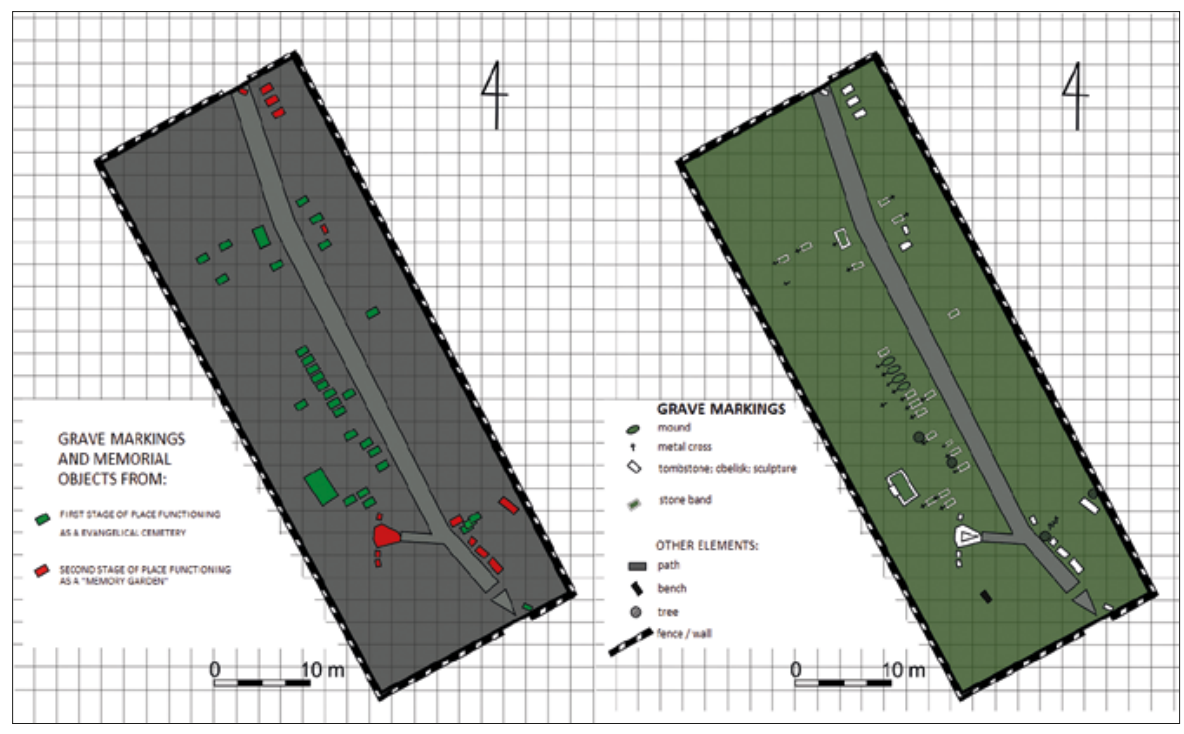

Fig. 12. Material representation of the resacralisation and commemoration taking place in the $19^{\text {th }}$-century Protestant cemetery in Justynów (East Łódź District) (prepared by A. Majewska).

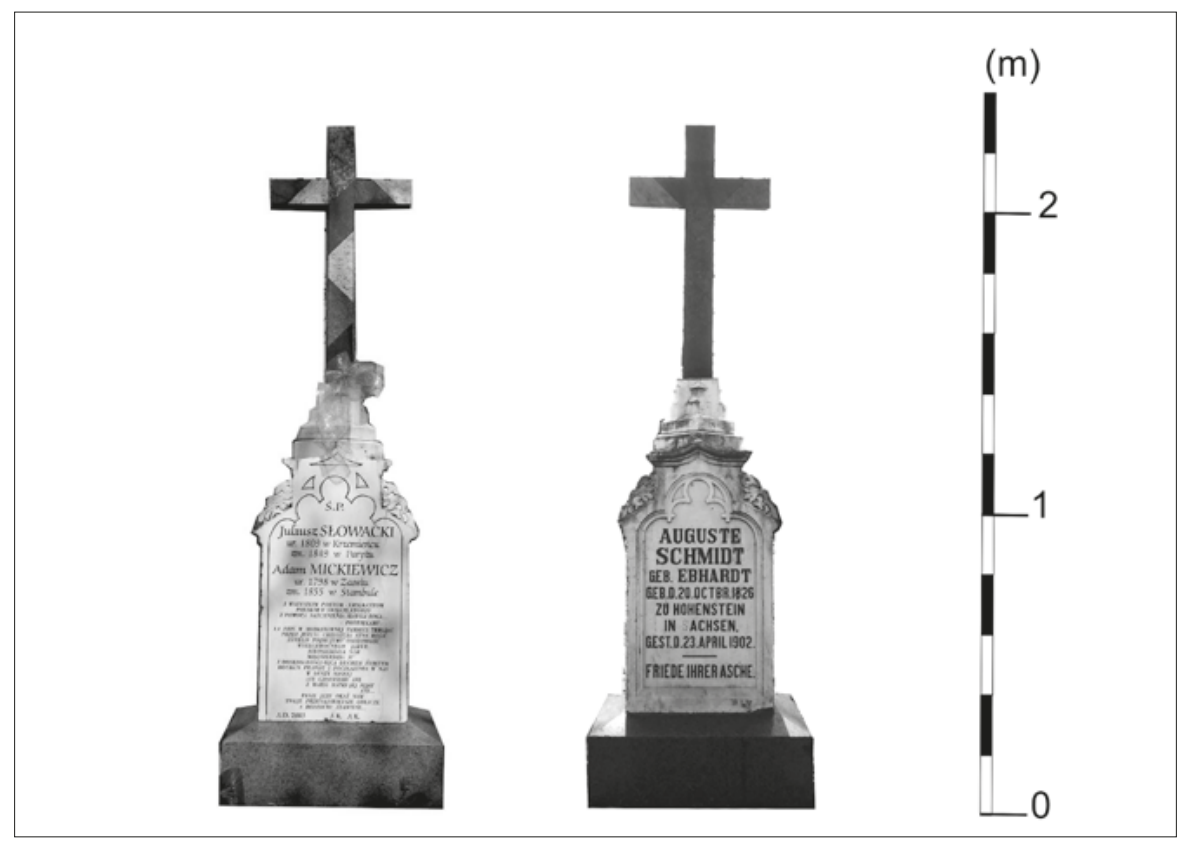

Fig. 13. Transformations of the original material substance of the cemetery in Justynów (photographed and prepared by A. Majewska). 


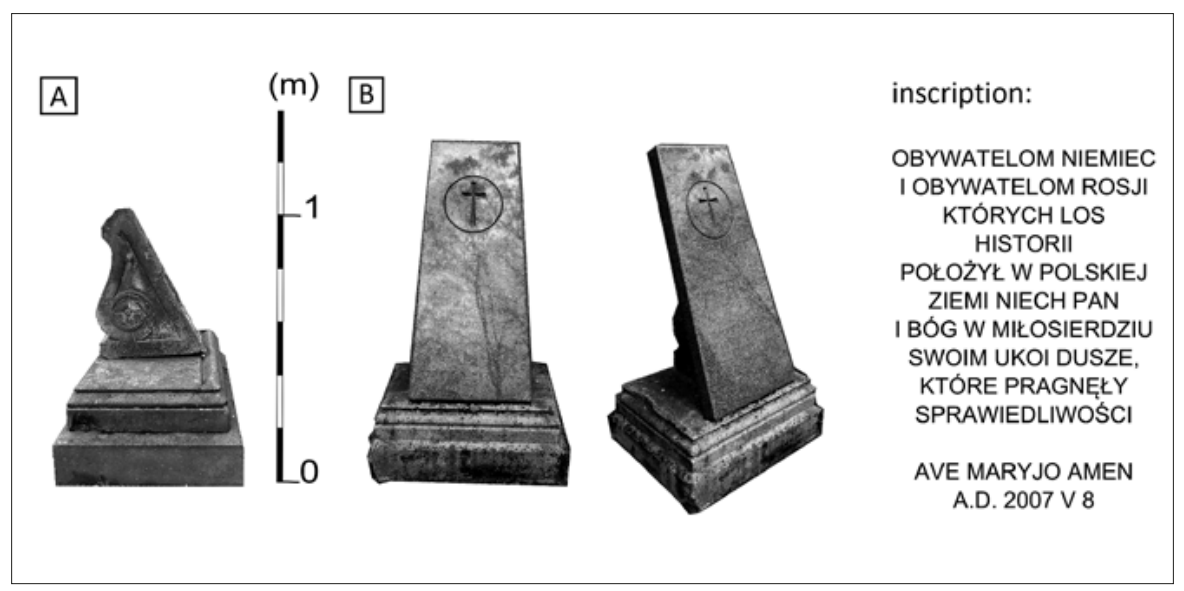

Fig. 14. Transformations of the original material substance of the cemetery in Justynów (photographed and prepared by A. Majewska).

A. Part of gravestone without epitaph table (XIX/XX century) (Justynów).

B. A gravestone plinth (XIX/XX century) with contemporary epitaph table (Justynów).

purpose of the place is a stele located near the northern gate of the cemetery with an inscription commemorating one of the people buried there: "IN THIS CEMETERY LIES / MICHAE WUDEL / I873-I927 / EVANGELICAL / DESCENDANT OF GERMAN SETTLERS".

It is also easy to identify commemorative phenomena in the form of tidying up and restoring the cemetery area, particularly with regard to protecting the graves and the spatial arrangement and making them more legible. They can accompany all the leading directions of cemetery transformations presented above. Usually incidental or sporadic, rarely regular and long-term activities, mostly related to maintenance, have many exemplifications, which is proven by, for example, publications with reports on and documentation of such undertakings as well as guidelines for similar activities (cf. Rydzkowska 2009: 96-IO5; Klimowicz et al. 2017). The reasons behind them are also similar. Assumptions and goals of such activities can be:

1. Scientific - mostly historical and related to restoration:

- Removal of vegetation and other elements destroying the cemetery's material elements (such as markings on the graves) or factors that can potentially destroy them;

- Cataloguing and inventorying the cemetery for research purposes, including in particular markings on the graves, historical elements, flora; drawing up documentation serving as a basis for monument restoration activities; 
2. Educational and related to the community;

- Education of the youth and broadening knowledge of regional history, sensitisation to the value and significance of cultural heritage and its protection etc.;

- Developing and maintaining local relationships and cultural identity.

\section{Conclusions. Processes Occurring in Cemeteries and Ephemeral and Passing Landscapes}

The issue of transformations taking place in cemeteries in the contemporary times is very complex, mostly due to the research perspective adopted: a description of changes observed in the time contemporary with the researcher, which, as G.E. Karpińska pointed out, implies even more clearly one's own interpretation of what we experience, i.e. 'reading' and 'writing' of these places (Karpińska 20I7: 2I). Such analysis can to some extent lose objectivity because we do not have the temporal distance necessary to define the long-term direction of the changes taking place (moreover, the contemporary scale is still open). Perhaps, in a hundred years, reflection on the leading directions of transformations of cemeteries in the contemporary times as we understand them today will differ from the one presented in this paper. This, in turn, leads to another issue, namely the question of the stability of the cemetery's landscape. Can a cemetery, as a place where natural and anthropogenic elements are strongly correlated like in a garden, be classified as a landscape with inherent ephemerality - the title continuity and decline over time? Of course, transformations occurring within the landscapes of cemeteries can be assessed based on objective scales used with regard to natural elements, such as the geological scale or the scale of the seasons, or anthropogenic elements, such as the scale of a human life or the scale of a historical period (Wojciechowski 20I0: 39). However, the landscape of a cemetery, even though natural elements form an important part of it, is established by people who, apart from organising funerals, intentionally plant vegetation there. Just like the underground part of a cemetery constitutes its essence, the above ground part, marked with symbols and having a specific material structure that defines its genius loci, constitutes to some extent ephemeral land art (Herman 20II: 28). According to A. Długozima: "from the end of the $\mathrm{I}^{8^{\text {th }}}$ century, to paraphrase the words of an art historian Jan Białostocki, we can talk about cemeteries - green temples of death, in which Nature and Art intertwine" (Długozima 20II: 25).

The landscape of a cemetery as a construct is thus nearly entirely an artificial product disrupting the natural cycle and processes taking place in nature. 
The anthropogenically made landscape of a cemetery undergoes rapid (on a human life scale) changes that can be easily identified, particularly when observing necropolises that are still used for burial purposes. Their ephemeral landscape is expressed in, for example, seasonal changes to their aesthetic aspects and appearance, which is connected with such occasions as the All Saints' Day and the All Souls' Day in Catholic and municipal cemeteries. We can also see spatial changes in cemeteries: an increase in the number of new graves, and physiognomic changes, such as liquidation of old graves and, in consequences, gravestones. Furthermore, cemeteries can be incorporated into the so-called passing landscape. According to Krzysztof Wojciechowski (2010: 40): "[passing landscapes - Author's note] are landscapes important aspects of which only change as a result of natural evolution of certain phenomena". Despite the fact that landscape ephemeras can be divided into two main categories: natural and caused by man, ephemerality connected with natural changes is particularly characteristic of the landscape. On the other hand cyclical changes, such as the vegetation cycle, are characteristic of seasonal landscapes that constitute a subcategory of passing landscapes. Natural and constantly progressing transformations of the landscape also determine its transience (cf. Brassley 1998; Palang et al. 2005).

The cemetery - despite the possible temporal orientation of the leading transformations towards 'continuation' occurring in functional or physiognomic and commemorative terms (e.g. with regard to the form of the historical place, being forcibly 'frozen' within the landscape) - remains only apparently constant in time. An inherent characteristic of cemeteries is their transience - 'stagnation' and 'disappearance' of the anthropogenic effect. These processes are sometimes accompanied by clearly distinct step-by-step directions of transformations referred to in this paper as 'desacralisation' and 'resacralisation'. Cessation of activity ultimately leads to the domination of natural (post)deposition processes and the transformation of cemeteries into archaeological sites.

Coming back to the initial assumptions, the paper distinguishes directions of the leading transformations of denominational cemeteries over time, identified based on the criterion of the anthropogenic effect, namely: continuation, stagnation/disappearance, resacralisation and commemoration, desacralisation. Directions of these transformations confirm the hypothesis that contemporary material structures and spatial arrangements of cemeteries result from the processes of diversification of the burial areas taking place over time under natural and cultural conditions. The main factor determining the changes occurring in these unique places is a specific type of the anthropogenic effect. The synthesis presented is an introduction to in-depth research concerning specific 
phenomena taking place in cemeteries in the contemporary times. Undertaking it is recommended or even necessary to extend knowledge and understanding of transformations in the material structure of these complex objects of cultural heritage, being places of remembrance, historical mementos, and sources of information about religious and local communities.

\section{Bibliography}

Act of the $31^{s^{t}}$ January 1959 on Cemeteries and Burials (Journal of Laws of 1959, no. 11, item 62).

Białas M. (no date), Smutny relikt, "Gazeta Częstochowska": http://gazetacz.com.pl/ artykul.php?id=2532 (access 4 XII 2017).

Brassley P. (1998), On the Unrecognized Significance of the Ephemeral Landscape, "Landscape Research", 23 (2), p. 119-132, https://doi. org/10.1080/01426399808706531

Brencz A. (2000), Niemieckie wiejskie cmentarze jako element krajobrazu kulturowego Środkowego Nadodrza, [in:] Z. Mazur (ed.), Wspólne dziedzictwo? Ze studiów nad stosunkiem do spuścizny kulturowej na Ziemiach Zachodnich i Pótnocnych, Instytut Zachodni, Poznań, p. 287-305.

Chojnicki Z. (1999), Podstawy metodologiczne i teoretyczne geografii, Bogucki Wydawnictwo Naukowe, Poznań.

Długozima A. (2011), Cmentarz a sztuka, [in:] J. Rylke (ed.), Krajobraz XXI wieku. Sztuka krajobrazu i w krajobrazie na tle przemian w sztuce XX i XXI wieku, Wydawnictwo Sztuka Ogrodu Sztuka Krajobrazu Beata J. Gawryszewska, Warszawa, p. 25-26.

Długozima A. (2016), Fenomen cmentarzy warmińskich i mazurskich $w$ aspekcie ich potożenia w krajobrazie, [in:] W. Knercer, B. Wacławik (ed.), Nekropolie Warmii i Mazur, Archiwum Państwowe, Olsztyn, p. 15-42.

Domańska E. (2018), Gleba cmentarna jako dziedzictwo, [in:] A. Marciniak, M. Pawleta, K. Kajda (ed.), Dziedzictwo we wspótczesnym świecie. Kultura. Natura. Cztowiek, Universitas, Kraków, p. 73-87.

Fordoński A. (2015), Brak sacrum jako problem cztowieka nowej epoki. Bluźnierstwo i profanacja - paradoksalny koniec pojęć, "Societas et Ius", 4, p. 35-46, https://doi. org/10.12775/SEI.2015.003

Gadowska I. (2017), Wielkomiejskie cmentarze żydowskie. Metamorfoza przestrzeni jako czynnik desakralizacji, [in:] J. Brejdak, D. Kacprzak, J. Madejski, B.M. Wolska (ed.), Adlojada. Kultura i profanacje, Muzeum Narodowe, Szczecin, p. 111-121.

Gładyś B., Górecki J. (2005), Pielgrzymki chasydów do grobów cadyków we wspótczesnej Polsce, "Peregrinus Cracoviensis", 16, p. 235-250. 
Herman K. (2011), Formy archetypiczne w sztuce krajobrazu, [in:] J. Rylke (ed.), Krajobraz XXI wieku. Sztuka krajobrazu i w krajobrazie na tle przemian w sztuce XX i XXI wieku, Wydawnictwo Sztuka Ogrodu Sztuka Krajobrazu Beata J. Gawryszewska, Warszawa, p. 28-31.

Jaszczak A., Dreksler B. (2013), Cmentarze - miejsca pamięci, tradycji i religii, "Cmentarze i ogrody w krajobrazie. O sacrum, symbolice, kompozycji i przemijaniu. Prace Komisji Krajobrazu Kulturowego", 22, p. 31-39.

Kacprzak D. (2017), Sacrum - profanum. Sacrilegium. Wstęp, [in:] J. Brejdak, D. Kacprzak, J. Madejski, B.M. Wolska (ed.), Adlojada. Kultura i profanacje, Muzeum Narodowe, Szczecin, p. 7-10.

Karpińska G.E. (2017), Cmentarz. Antropologiczna lektura przestrzeni i pamięci na przyktadzie wiejskiego cmentarza w Ztotym Potoku, "Literatura Ludowa", 1, p. 21-31, https://doi.org/10.12775/LL.1.2017.002

Kijowska J., Kijowski A., Rączkowski W. (2011), Krajobraz i polityka-wybrane aspekty wptywu decyzji politycznych na zmiany krajobrazu w Polsce, "Niematerialne wartości krajobrazów kulturowych. Prace Komisji Krajobrazu Kulturowego”, 15, p. 103-115.

Klimowicz T., Sygowski P., Tarajko M., Trzciński A. (2017), Ogrodnicy pamięci. Cmentarze żydowskie. Podręcznik dobrych praktyk w ochronie dziedzictwa lokalnego, Stowarzyszenie Studnia Pamięci, Lublin.

Knercer W. (2016), Ślady na ziemi - cmentarze, [in:] W. Knercer, B. Wacławik (ed.), Nekropolie Warmii i Mazur, Archiwum Państwowe, Olsztyn, p. 9-14.

Kolbuszewski J. (1996), Cmentarze, Wydawnictwo Dolnośląskie, Wrocław.

Kopczyńska E. (2010), Udomawianie przestrzeni. Dynamika tożsamości miejsca na Ziemiach Zachodnich, [in:] A. Bukowski, M. Lubaś, J. Nowak (ed.), Spoteczne tworzenie miejsc: globalizacja, etnicznośc, władza, Wydawnictwo Uniwersytetu Jagiellońskiego, Kraków, p. 187-202.

Laberschek J. (1991), Sieć osadnicza okolic Mstowa i Lelowa w I potowie XIII wieku. Problem granic Opola Mstowskiego, "Studia Historyczne", 4, p. 517-533.

Lewicka B. (2012), Nekropolis, [in:] K. Bierwiaczonek, B. Lewicka, T. Nawrocki (ed.), Rynki, malle i cmentarze. Przestrzén publiczna miast ślaskich $w$ ujęciu socjologicznym, Zakład Wydawniczy "Nomos”, Kraków, p. 80-95.

Majewska A. (2016a), Dziedzictwo opuszczone na przyktadzie cmentarzy żydowskich województwa ślaskiego. Uwarunkowania i zagrożenia naturalne, [in:] M. Winograd (ed.), Wspólne dziedzictwo kulturowe. Dialog kultury z natura, Białystok, p. 250-270.

Majewska A. (2016b), Żydowskie dziedzictwo religijne w przestrzeni województwa ślaskiego (a manuscript of an MA thesis), Łódź. 
Majewska A. (2017), Surface Prospection of Burial Grounds and New Research Tools (On the Example of the Study of Changes in Cemetery Boundaries), "Journal of Geography, Politics and Society”, 7 (1), p. 60-69, https://doi.org/10.4467/ 24512249JG.17.008.6207

Malchrowicz-Mośko E., Grzesiak H. (2013), Turystyka religijna a ochrona dziedzictwa kultury żydowskiej na przyktadzie Leżajska, "Peregrinus Cracoviensis", 24 (1), p. 27-44.

Myga-Piątek U. (2005), Historia, metody i źródta badań krajobrazu kulturowego, [in:] A. Szponar, S. Horska-Schwarz (ed.), Przemiany środowiska przyrodniczego polski a jego funkcjonowanie. Problemy ekologii krajobrazu, IGiGP UJ, Kraków, p. 71-77.

Palang H., Fry G., Jauhiainen J., Jones M., Sooväli H. (2005), Editorial: Landscape and Seasonality - Seasonal Landscapes, "Landscape Research", 30 (2), p. 165-172, https://doi.org/10.1080/01426390500044259

Rydzewska A., Krzyżaniak M., Urbański P. (2011), Niegdyśs sacrum, dziś profanum - dawne cmentarze ewangelickie Poznania i okolic, "Prace Komisji Krajobrazu Kulturowego", 15, p. 64-72.

Rydzkowska J. (2009), O cmentarzach, [in:] L. Graczyk, J. Rydzkowska, M. Ratkowska (ed.), I nastata cisza... Rakutowo na Kujawach, Łódź, p. 9-105.

Rykała A. (2007), Muzutmanie w polskich dziejach i przestrzeni, "Acta Universitatis Lodziensis. Folia Geographica Socio-Oeconomica", 8, p. 39-61.

Rykała A. (2011), Mniejszość religijna - mniejszość etniczna - wspólnota kulturowa. Uwagi na temat genezy, aktywności i tożsamości Karaimów w Polsce, "Acta Universitatis Lodziensis. Folia Geographica Socio-Oeconomica", 11, p. 1-45.

Sacrum pogańskie - sacrum chrześcijańskie... Kontynuacja miejsc kultu we wczesnośredniowiecznej Europie Środkowej (2010), K. Brachy, C. Hadamika (ed.), Wydawnictwo DiG, Warszawa.

Sakson A. (2017), Spoteczność ewangelickich Mazurów - przesztość i teraźniejszość, [in:] R. Bażanowski, B. Wacławik (ed.), Reminiscencje Reformacji. Prusy-Mazury 1517-2017, Archiwum Państwowe, Olsztyn, p. 109-125.

Stownik wyrazów obcych (2000), E. Sobol (ed.), PWN, Warszawa.

Stachowiak A. (2015), Niemieckie cmentarze na Ziemiach Zachodnich jako miejsca niepamięci, "Zeszyty Naukowe Uniwersytetu Jagiellońskiego. Prace Etnograficzne”, 43 (2), p. 123-140.

Stachowiak A. (2016), Profanacja przestrzeni sacrum. Kulturowy wymiar dewastacji niemieckich cmentarzy na Powiślu, [in:] J. Adamowski, M. Tymochowicz (ed.), Sacrum w kulturze tradycyjnej i wspótczesnej, Wydawnictwo Uniwersytetu Marii Curie-Skłodowskiej; Polskie Towarzystwo Ludoznawcze, LublinWrocław, p. 87-105. 
Studium uwarunkowań i kierunków zagospodarowania przestrzennego gminy Andrespol (2015), Pracowania planowania przestrzennego Dorota Brzozowska.

Szacka B. (2006), Czas przeszty, pamięć, mit, Wydawnictwo ISP PAN, Warszawa. Wałkowska J. (2017), Cmentarze ewangelickie z perspektywy archeologii: problemy i możliwości badawcze, [in:] J. Kołacki, I. Skórzyńska (ed.), "Ziemia skrywa kości". Zapomniane krajobrazy pamięci-cmentarze protestanckie $w$ Wielkopolsce po 1945, Instytut Historii UAM, Poznań, p. 91-103.

Widawski J. (1973), Miejskie mury obronne w państwie polskim do początku XV wieku, Wydawnictwo MON, Warszawa.

Wojciechowski K. (2010), Wartości i walory krajobrazów przemijających i efemerycznych, [in:] D. Chylińska, J. Lach (ed.), Studia krajobrazowe a ginace krajobrazy, Uniwersytet Wrocławski. Instytut Geografii i Rozwoju Regionalnego, Wrocław, p. 37-42.

Wrzesiński J. (2014), Krajobraz funeralny - pamięć nieobecnych, [in:] B. Frydryczak (ed.), Krajobrazy i ogrody. Ujęcie interdyscyplinarne, Wydawnictwo Poznańskiego Towarzystwa Przyjaciół Nauk, Poznań, p. 155-167.

Żurkowska T. (2008), Mazurskie cmentarze. Symbole w krajobrazie, Wydawnictwo Borussia, Olsztyn.

Żydzi lelowscy. Obecność i ślady (2006), M. Galas, M. Skrzypczyk (ed.), Wydawnictwo Austeria, Kraków.

\section{Online Sources}

Muslim Religious Community in the Republic of Poland: http://www.mzr.pl (access 2 XII 2017).

Wiejskie cmentarze ewangelickie województwa łódzkiego:

http://www.cmentarzeewangelickie-lodzkie.pl/justynow.htm (access 4 XII 2017).

Wirtualny Sztetl: https://sztetl.org.pl/pl/miejscowosci/l/443-lubliniec/

114-cmentarze/19944-cmentarz-ul-11-listopada-18 (access 4 XII 2017).

Wspólnota bez Bram Mumon-Kai: http://www.mumon-kai.com/polen.html

(access 2 XII 2017).

http://www.geoportal.gov.pl

\section{Other}

Cemetery Card no. 1909, filled in by D. Gospodarek, 1989, archive of the Ełk branch of the Provincial Office of Monument Preservation.

A photogrammetric photograph, 1967, file no. 8_6773, from the collection of the Main Centre of Geodetic and Cartographic Documentation. 


\title{
Summary
}

\section{Continuity and Decline. Temporal Expression of Denominational Cemeteries in Contemporary Times}

\begin{abstract}
The study attempts to systematize the leading transformations observed nowadays in denominational cemeteries located in Poland. The time frame of the analyses was limited to the period from the end of the Second World War to the present. Four basic types of transformations have been distinguished and divided into two main directions of changes reported over time, namely: harmonious temporal expression (stagnation/decline, continuation) and disharmonious temporal expression (desacralisation, resacralisation and commemoration). Each type of transformation is discussed separately based on selected examples. However, it needs to be emphasised that the proposed division is not disjunctive as considering the multitude of factors that determine changes in the material structures of cemeteries, processes sometimes run parallel to each other or overlap in time.
\end{abstract}

Keywords: cemeteries, archaeology of the contemporary past, historical geography, cultural heritage, profanation, secularization, religious objects

\section{Streszczenie}

\section{Trwanie i zanikanie. Ekspresja temporalna cmentarzy wyznaniowych we współczesności}

W opracowaniu podjęto próbę systematyzacji wiodących przekształceń zachodzących we współczesności w przestrzeni cmentarzy wyznaniowych znajdujących się na terenie Polski. Cezurę czasową analiz ograniczono do okresu trwającego od zakończenia drugiej wojny światowej do chwili obecnej. Wyróżniono cztery zasadnicze rodzaje przekształceń podzielone na dwa główne kierunki przemian zachodzących w czasie: harmonijną ekspresję temporalną (zastój/zanik; kontynuację) oraz dysharmonijną ekspresję temporalną (desakralizacja; resakralizacja i komemoracja). Każdy rodzaj przekształceń został omówiony osobno na wybranych przykładach. Należy jednak podkreślić, że zaproponowany podział nie ma charakteru rozłącznego, gdyż biorąc pod uwagę mnogość czynników determinujących zmiany struktur materialnych cmentarzy, niekiedy procesy zachodzą równolegle lub zazębiają się w czasie.

Słowa kluczowe: cmentarze, archeologia współczesności, geografia historyczna, dziedzictwo kulturowe, profanacja, profanizaja, obiekty religijne

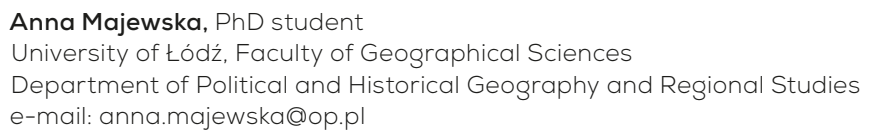

